\title{
Are Emotionally Intelligent EFL Teachers More Satisfied Professionally?
}

\author{
Mohammad Hossein Hekmatzadeh \\ Department of English Language Teaching, Fars Science and Research Branch, Islamic Azad University, Marvdasht , Iran \\ E-mail: m.h.hekmatzadeh@gmail.com \\ Laleh Khojasteh (Corresponding author) \\ Shiraz University of medical Sciences, English department, Shiraz, Iran. \\ E-mail: khojastehlaleh@yahoo.com \\ Nasrin Shokrpour \\ Shiraz University of Medical Sciences, English department, Shiraz, Iran. \\ E-mail: shokrpourn@gmail.com
}

Received: 16-09-2015

Accepted: 09-12-2015

Published: 01-03-2016 doi:10.7575/aiac.ijalel.v.5n.2p.97

Advance Access Published: December 2015

URL: http://dx.doi.org/10.7575/aiac.ijalel.v.5n.2p.97

\begin{abstract}
Despite the fact that Intelligence Quotient (IQ) is an important factor in one's success in terms of working environment, it is believed that emotional quotient or EQ plays a more important role. With that in mind, this study investigated the relationship between emotional intelligence and job satisfaction of English as Foreign Language (EFL) teachers who work at private language institutes in Iran/Shiraz. Furthermore, this study tried to answer whether there is a significant difference between emotional intelligence and job satisfaction of Iranian's EFL teachers in terms of gender. A 90-item Bar-On questionnaire was used to measure the teachers' emotional intelligence; also, a modified version of Karavas's (2010) job satisfaction scale was used to see how satisfied our teachers are with their teaching career. To answer the research question, Pearson Product-Moment Correlation Coefficient statistical test was run. The results showed that there was a positive and significant correlation between emotional intelligence and job satisfaction of EFL teachers in Iran/Shiraz. Furthermore, the results revealed that there was a statistically significant difference in emotional intelligence between EFL male and female teachers, but there was no statistically significant relationship between Iranian EFL teachers' job satisfaction in terms of gender. Based on our findings, it is suggested that some preparatory courses aiming at enhancing the important psychological traits such as emotional intelligence should be incorporated in educational programs designed for novice teachers so that it will contribute to pedagogical improvement.
\end{abstract}

Keywords: Emotional intelligence, Job satisfaction, EFL teachers

\section{Introduction}

Money, manpower, strategy and material are thought of as four significant pillars of any organization, among which manpower is the most important one (Ghazi, Ali, Shahzada \& Israr, 2010). In addition, in a social institution like classroom, teachers' vital role cannot be overlooked (Ghazi, et al. 2010). One of the valuable assets of any country is its quality teachers who form the strength of a nation in progression of "human capital for a knowledge-based economy" (Kappagoda, 2011, p.1). This is a crucial role because without a combination of teachers' skill, knowledge and experience, we wouldn't have a coherent system to lead the students to a better achievement of their goals. This can be seen in a lot of school effective research which found a strong relationship between the students' learning and their progress with teachers' expectations and their quality of teaching (Sammons, 2007; Sammons \& Bakkum, 2012).

Nonetheless, are teachers content with what they do? In spite of their highly valued roles, many teachers are often reported to be not happy with their jobs due to the challenges and great demands on the part of the teachers (Salim, Nasir, Arip \& Mustafa, 2012). Although one must be careful in generalizing the teachers' dissatisfaction to every country and all cultural contexts, it has been reported that teachers are not happy with their jobs because of their low salary, reduced autonomy and heavy workloads, to name a few (Dinham \& Scott, 2000; Fenech, 2006). When this occurs, it is obvious that unhappy teachers are less capable of doing their expected job; therefore, they feel less competent regarding their awareness of the course and lessons and probably it finally results in their less faith in controlling their classrooms. Besides, teachers' demographic characteristics, their education degree, worksettings, income, their students' approach towards learning, and workload are other reasons which can influence the teachers' satisfaction or dissatisfaction (Wright \& Davis, 2003; Kim, 2004; Borzaga \& Tortia, 2006). As it can be seen, all the factors cited above are economic, physical and sociological ones. So it is also important to highlight more on psychological factors contributing to the teachers' job satisfaction (hereafter JS). One of these factors is the concept of emotional intelligence (hereafter EI). Recently, it is an "emotional knowledge" rather than "academic knowledge" 
which is highlighted most since it sounds that EI is much more powerful than academic intelligence in the employee's efficiency and achievement of an organization's goals (Goleman, 1995, p.12). To state it differently, despite the fact that Intelligence Quotient (IQ) is an important factor in one's success, in terms of working environment, emotional quotient or EQ plays a more important role. Lying beneath this is the belief that teachers with high EI can more probably achieve success in the classroom environment (Kremenitzer \& Miller, 2008). Therefore, personality and personal traits of teachers, including their EI, must be taken into account along with other factors in studying job satisfaction.

Many studies have found relationships between JS and situational factors, such as task attributes, salary, promotion, supervision, working conditions, and subjective well-being among executives (Wiener \& Vardi, 1980; Parker, Baltes, Young, Huff, Altmann, Lacost, Roberts, 2003; Kulshrestha \& Sen, 2006). However, teachers' emotions should be emphasized here because teaching can be one of the most stressful occupations (Chaplain, 2008). This, in turn, can lead to teacher turnover which eventually can have a negative effect on the students' performance and learning (Levy, Fields, \& Jablonski, 2006). Chen (2007) also reported a positive relationship between stress and turnover and job dissatisfaction. Accordingly, regarding the statistics published related to teachers' turnover and burnout and their general dissatisfaction as well as global financial problems with which everyone is faced including teachers particularly teachers in Iran who are faced with inflation due to related sanctions (Tabatabaee Yazdi, Motallebzadeh \& Ashraf, 2013), it is important to study EFL teachers' emotional intelligence in those who teach at private language centers without any job security, and to see if it has a relationship with their job satisfaction. Because if there is a relationship between these two variables, then teacher training courses should incorporate social and emotional skills training programs, in this case, for TESL students.

Another reason for doing this study is that most of the findings of the studies are mixed. A number of studies revealed weak to moderate relationships between EI and JS (Carmeli, 2003; Vacola, Tsaousis \& Nikolaou, 2003; Kafetsios \& Loumakou, 2007) and some of them found a positive significant relationship between the two (Alam, 2009; Wong \& Law , 2002 ). So, it can be seen that this discrepancy among the results of various studies especially regarding the employees in different sectors rather than teaching cannot really be convincing to assume that there is definitely a relationship between EI and JS of EFL teachers working at private sectors.

Another significance of this study is that although an experimental relationship exists between the two concepts, a great number of studies in this regard have been carried out in Western countries (Alam, 2009). Hence, it seems that there is a gap in similar investigations in Asian contexts. Yet those studies which have been conducted in Asian settings like Iran have just focused on secondary school teachers (e.g. Yahyazadeh-Jeloudar, 2012), or physical education teachers (e.g. Mousavi, Yarmohammadi, Nosrat, Tarasi, 2012). As a result, comprehensive research on the relationship between EI and JS of EFL teachers in Asian settings is scanty.

Since the studies described above have indicated the contributing effect of EI on JS, and the importance of this area of research has been shown in some factories and organizations rather than in the education system, especially among EFL teachers, the main objective of this study was to analyze EFL teachers' EI and their JS in private language institutes in Iran/Shiraz.

\subsection{Emotional Intelligence}

The term EI has been coined by Mayer, DiPaolo and Salovey (1990). They defined it as "a set of interrelated abilities to perceive, understand, articulate, evaluate, regulate and harness emotions in one and others" (Mayer, DiPaolo \& Salovey, 1990, p 14). In fact, EI is known as a non-cognitive facet of intelligence which makes one able to recognize particular emotions and agitations in oneself and others to apply this information in order to manage one's thoughts and behaviors (Cherniss, 2000). This is almost distinct from what has been traditionally known as cognitive facet of intelligence that highlights memory and problem solving (Stein \& Book, 2006). People with a high level of EI can cope with environmental requirements and tensions which account for $80 \%$ of their achievements in life and work environment (Goleman, 1995; Bar-On, 1997). According to Goleman (2001, p. 26), four main constituents of EI are "1) selfawareness which is about knowing one's emotions, preferences, resources and perceptions; 2) self-management which is the ability one has to manage his or her emotions, incentives and resources in order to reach his/her goals; 3) social awareness which is about being aware of others' emotions, requirements and interests including understanding social networks; and finally 4) social skills which is the ability one has to inspire and motivate others to achieve the desired goals". Thus, it is evident that the above-mentioned skills are verbal and non-verbal abilities which a teacher must have in an emotional setting filled with joy, anger, boredom, fear (of peers or teacher) called classroom.

One of the pioneering studies in this regard is Bar-On's (1997, p 35) model of EI which was developed in order to answer the question, "Why are some individuals more able to succeed in life than others?" Bar-On studied the psychological literature on personality traits which seemed related to life success and found five extensive areas of performance, related to success, including (a) intrapersonal abilities, (b) interpersonal abilities, (c) ability to be modified, (d) stress control, and (e) overall mood. Each wide area is again subdivided. For instance, intrapersonal abilities are categorized into "emotional self-awareness assertiveness, self-regard, self-actualization, and independence" (Izaguirre, 2008, p.34).

We can generalize this to teachers in the classroom and state if teachers do not own essential skills, awareness and talent, they cannot be an effective source of knowledge. Recently, the notion of the EI amidst teachers has been paid attention in the educational institutions because of its great significance. As stated earlier, EI is a sort of social intelligence that enables individuals to manage their own and others' emotions in order to apply these emotions to adjust life. Therefore, this ability is really needed to make the teachers' functioning influential (Hans, Mubeen \& Al Ghabshi, 2013). 


\subsection{Job Satisfaction}

Job satisfaction is a positive delightful response an individual has for his or her occupation experience (Milkovich \& Boudreau, 1988). Syptak, Marslandand and Ulmer (1999, p. 23) proposed this definition for JS: "peoples' affective relation to their work role, and a function of the perceived relationship between what they wanted from the job, and what they perceived it was offering". Throughout the last decades, due to certain reasons JS has been the target of several research studies. First of all, there is this strong belief that JS is a powerful predictor of general wellbeing of a person in the job setting (Argyle, 1989). Next, high JS is followed by developed work function regarding quantity and quality since the features of the job suits the anticipations of the employee. Finally, JS cannot merely affect work productivity but also influence work effort, the quality of the working condition, staff turnover and retention, payment level, the perceived impartiality of the promotion system within an organization, and many more (Rowden, 2002). Classification of these factors shows that JS is generally related to sociological perspective (situational factors) and psychological perspective (personal factors) (Heller, Judge, \& Watson, 2002). Situational factors comprise job associated conditions such as payment, chance for promotion, working situations, and job characteristics like "task identity, task significance, skill variety, autonomy, and feedback" (Saavedraand \& Kwun, 2000, p. 4). Personal factors consist of personality nature, features, self-respect, drives, and feelings.

Moreover, teacher JS is considered as "a predictor of teacher retention, a determinant of teacher commitment and a contributor to teacher effectiveness" which leads to the teacher's performance enhancement and eventually the ability to have a positive effect on the students' final performance (Shann, 1998, p. 67). Many teachers are believed to choose teaching as an occupation since they merit the innate rewards which they get and since they feel the pleasure of the emotional and personal advantages of the job itself, including personal improvement and a sense of success (Iwanicki, 2001). Indeed, most of the teachers choose this profession since they want to help others and look for the chance to improve personally and develop the public services (Jones, 2002). To put it differently, the utmost reason for this common enthusiasm among teachers is their competency to cause positive differences in young people's lives.

What we can conclude from the above-cited discussions on EI and JS is that teachers are not only influenced by outer factors but also by inner factors like feelings and personality characteristics. Emotional or affective intelligence is one of these personality traits (Mayer, Salovey \& Caruso, 2000). Knowledge of interpersonal feelings can aid in the management of negative senses and emotions; therefore, the person will enjoy a better performance in his/her profession. Better performance will also create a basis for JS. EI can be intimately linked to JS and job success since as it was explained earlier, EI is concerned with understanding other people. Also, it involves adapting and dealing with the surrounding environment to become more successful in coping with environmental requirements (Bar-On, 1997). Thus, according to Bar-On (1997), EI greatly predicts one's JS since it can reflect on how a person utilizes emotional awareness to an immediate condition. Finally, since abandoning data can be found in the reviewed literature on teacher attrition and dissatisfaction and because what appears to draw teachers to this occupation is somehow distinct from what they really do experience in the community, the relationship between EI and EFL teachers' JS is worth investigating. Because including EI in any educational system may enhance pre-service, novice and in-service teachers' classroom function, respectively.

\subsection{Research Questions}

1- Is there any relationship between Iranian EFL teachers' emotional intelligence and job satisfaction?

2- Is there any difference between male and female EFL teachers in terms of emotional intelligence?

3- Is there any difference between male and female EFL teachers in terms of job satisfaction?

\subsection{Hypothesis}

Based on the objectives of the research, the following hypotheses have been formulated:

H1: There is no statistically significant relationship between Iranian EFL teachers' emotional intelligence and job satisfaction.

H2: There is no statistically significant difference between male and female EFL teachers in terms of emotional intelligence.

H3: There is no statistically significant difference between male and female EFL teachers in terms of job satisfaction.

\section{Method}

In order to conduct the present study, the quantitative method was used. The design chosen for the current research is the correlational research approach. As Creswell (2003) argued, in contrast to a qualitative research design which deals with interpreting, understanding, and conceptualizing the focal phenomenon, quantitative research approach is the most suitable method for describing the trends and explaining the scope of associations between variables. Although correlation is not able to reasonably determine causation, "high correlation values should suggest causal relationships" (Barr, Kamil, Mosenthal \& Pearson, 2002, p. 48). According to Barr et al. (2002, p. 48), "Such suggested relationships have to be verified by other experimental means" (Barr et al., 2002, p. 48). Thus, in the present study, descriptive statistics were applied in order to summarize the characteristics of the sample and measure the principal variations and tendency. The current study applied a quantitative correlational design as an appropriate method for investigating the nature and comprehending the extent of connections between variables. There were two distinct variables in this research; one dependent and the other independent. Iranian EFL teachers' job satisfaction is the dependent variable of the study, while teachers' emotional intelligence is the independent variable.

\subsection{Sampling}


Two-step cluster sampling was utilized to choose six English private institutes in Shiraz. First, 6 out of 20 language centers were selected. The criteria of choosing these 6 language centers were based on the fact that all these centers were located in a similar district with a moderate economic level. Since this study had focused on the EFL teachers who were teaching at private language centers, the researchers thought if they choose language centers located at the upper middle class districts, the teachers would be paid more and this would indirectly affect the results of this study. The same was true about language centers located at lower middle class districts. So, the sampling at this stage was based on purposive sampling criteria. In the second step, all teachers included in these six centers were asked to participate in this study based on convenient sampling.

\subsection{Participants}

The participants of the present study were male and female teachers who had temporary positions in private institutes. The sample size comprised 70 participants $(n=70) ; 30$ were males and 40 females. The participants' age ranged between 22 and 50 years, and their teaching experience ranged from 1 to 35 years. As opposed to English language teachers who work and teach at high schools, this study aimed to choose EFL teachers who teach at private language institutes because the researchers thought that most of the EFL teachers who teach at these particular institutions are not permanently employed. Thus, they may have less job security, which may result in more meaningful and beneficial outcome for the current study. Moreover, since education in public schools is free, there is no competition among them to attract more students; in contrast, there is a strong competition among private language schools to draw in more and more students (Pishghadam \& Sahebjam, 2012).

\subsection{Instruments}

In this study, the short version of Bar-On EQ-i Self Report Scale was used to measure Iranian EFL teachers' emotional intelligence. The original scale consists of 133 questions but the short version which was recently published consists of 90 items. This is a five-point Likert scale ranging from $1=$ highly satisfying to $5=$ highly dissatisfying in a checklist form. It is worth mentioning that although the participants of this study were EFL Iranian teachers, we decided to use the Persian adaptation of this scale because we did not have any knowledge about the English proficiency level of the participants of this study, though they were EFL teachers. The validity and reliability of the Persian version of the questionnaire were examined via 30 teachers from other language institutes which were not part of the sample group. In the current study, Cronbach Alpha test was utilized to determine the reliability and the result was 0.94 which proved to be highly satisfactory.

The second questionnaire used in this study was a modified version of Karavas's (2010) job satisfaction scale which was specifically devised for EFL teachers. This scale consists of 33 items in the form of five-point Likert scale and has four facets of job satisfaction including income satisfaction (4 questions), working condition satisfaction (14 questions), motivation to teach (12 questions), and satisfaction of system-based level (3 questions). This scale, too, was translated into Persian and piloted on 30 EFL teachers. The result of the reliability test (alpha) was 0.96 . To answer the research question, we used Pearson Product-Moment Correlation Coefficient.

\subsection{Procedure}

This study was conducted in six private language institutes in Shiraz, south-western Iran during August and November 2013. Teachers were permitted to take the questionnaire home, complete it and submit it next session to the researcher. At the same time, the job satisfaction questionnaire was handed to the teachers. They filled out the questionnaire at home and, the next session, gave them back to the researcher, likewise. To achieve a credible evaluation by the teachers, the researcher described the goal of filling the questionnaires and promised them that their ideas and perspective would be strictly confidential.

\subsection{Data Analysis}

This is an exploratory study, as its main goal is to reach a better perception of the EFL teachers' emotional intelligence and job satisfaction. To study the common distribution, descriptive statistics were utilized. Pearson correlation was applied to determine the association between EFL teachers' EI and job satisfaction. Furthermore, t-test was used to see if there is any difference between male and female EFL teachers in terms of emotional intelligence and job satisfaction.

\section{Results}

To see if there is any relationship between Iranian EFL teachers' EI and their JS, Pearson's correlation coefficient test was run to analyze the data (Table 1).

Table 1. Correlation analysis between teachers' EI and JS

\begin{tabular}{llll}
\hline & & Total EI & Total JS \\
\hline Total EI & Pearson Correlation & 1 & $.450^{* *}$ \\
& Sig. (2-tailed) & & .000 \\
& $\mathrm{~N}$ & 70 & 70 \\
\hline TOTAL JS & Pearson Correlation & $.450^{* *}$ & 1 \\
& Sig. (2-tailed) & .000 & \\
& $\mathrm{~N}$ & 70 & 70 \\
\hline
\end{tabular}

**. Correlation is significant at the 0.01 level (2-tailed). 
IJALEL 5(2):97-107, 2016

Since the Sig. (2-tailed) value is 0.000 and this value is less than .05 , we can conclude that there was a statistically significant correlation between Iranian EFL teachers' EI and their JS. In this study $r=450$; this reveals a moderate relationship between the variables of this study.

The relationship between EI and four essential parts of JS was analyzed too and the results are shown in Table 2.

Table 2. Correlation analysis between teachers' EI and income

\begin{tabular}{llll}
\hline & & Total EI & INCOME \\
\hline Total EI & Pearson Correlation & 1 & -.004 \\
& Sig. (2-tailed) & & .973 \\
& $\mathrm{~N}$ & 70 & 70 \\
\hline INCOME & Pearson Correlation & -.004 & 1 \\
& Sig. (2-tailed) & .973 & \\
& $\mathrm{~N}$ & 70 & 70 \\
\hline
\end{tabular}

As seen in Table 2, the Sig (2-Tailed) value is greater than .05 (sig=0.973); then, we can conclude that there was no statistically significant correlation between Iranian EFL teachers' EI and their income.

\begin{tabular}{llll}
\hline \multicolumn{3}{l}{ Table 3. Correlation analysis between teachers' EI and work condition } \\
\hline \multirow{2}{*}{ Total EI } & Total EI & $\begin{array}{l}\text { Working } \\
\text { condition }\end{array}$ \\
& Pearson Correlation & 1 & $.321^{* *}$ \\
& Sig. (2-tailed) & .007 \\
& $\mathrm{~N}$ & 70 & 70 \\
\hline Working condition & Pearson Correlation & $.321^{* *}$ & 1 \\
& Sig. (2-tailed) & .007 & \\
& $\mathrm{~N}$ & 70 & 70 \\
\hline
\end{tabular}

As it can be seen in Table 3, the Sig (2-Tailed) value is greater than $.05(\mathrm{sig}=.007)$; it can be concluded that there was no statistically significant correlation between Iranian EFL teachers' EI and their working condition.

Table 4. Correlation analysis between teachers' EI and motivation to teach

\begin{tabular}{ll|l|l}
\hline & & Total EI & $\begin{array}{l}\text { Motivation to } \\
\text { teach }\end{array}$ \\
\hline Total EI & Pearson Correlation & 1 & $.573^{* *}$ \\
& Sig. (2-tailed) & & .000 \\
& $\mathrm{~N}$ & 70 & 70 \\
\hline Motivation to teach & Pearson Correlation & $.573^{* *}$ & 1 \\
& Sig. (2-tailed) & .000 & \\
& $\mathrm{~N}$ & 70 & 70 \\
\hline
\end{tabular}

The results revealed that there was a significant correlation between EFL teachers' EI and their motivation to teach ( $\mathrm{r}=$ $0.573, \mathrm{p}=0.000$ ) and the correlation among variables was moderate.

Table 5. Analysis of teachers' EI and satisfaction level of system base factor

\begin{tabular}{llll}
\hline & & Total EI & $\begin{array}{l}\text { Satisfaction level } \\
\text { of system base } \\
\text { factor }\end{array}$ \\
\hline Total EI & Pearson Correlation & 1 & .216 \\
& Sig. (2-tailed) & .072 \\
& $\mathrm{~N}$ & 70 & 70 \\
\hline Satisfaction.level.0f.system.b & Pearson Correlation & .216 & 1 \\
ace.factor & Sig. (2-tailed) & .072 & \\
& $\mathrm{~N}$ & 70 & 70 \\
\hline
\end{tabular}


As it can be seen in Table 5, the Sig (2-Tailed) value is greater than .05(sig=.072); then, we can conclude that there was no statistically significant correlation between Iranian EFL teachers' EI and system base factor.

To see if there is any difference between Iranian EFL teachers' emotional intelligence in terms of gender, descriptive statistics as well as independent samples t-test were run to analyze the data. The summaries are as follows:

Table 6. Descriptive statistics for EQ among males and females teachers.

\begin{tabular}{llllll}
\hline & Gender & $\mathrm{N}$ & Mean & Std. Deviation & Std. Error Mean \\
\hline \multirow{2}{*}{ Total EQ } & man & 30 & 300.97 & 42.484 & 7.756 \\
& woman & 40 & 331.53 & 34.379 & 5.436 \\
\hline
\end{tabular}

According to Table 6, there was a difference in the scores for emotional intelligence of male and female teachers (EQ of men $(M=300.97, S D=42.48)$ and $E Q$ of women $(M=331.53, S D=34.379)$. The result of the t-test indicated that the female teachers' EQ scale scores were more than those of the men.

Table 7. Independent sample t-test for both groups: EQ among males and females teachers

\begin{tabular}{|c|c|c|c|c|c|c|c|c|c|c|}
\hline & & \multicolumn{2}{|c|}{$\begin{array}{l}\text { Levene's Test for } \\
\text { Equality of } \\
\text { Variances }\end{array}$} & \multicolumn{7}{|c|}{ t-test for Equality of Means } \\
\hline & & \multirow[t]{2}{*}{$\mathrm{F}$} & \multirow[t]{2}{*}{ Sig. } & \multirow[t]{2}{*}{$\mathrm{t}$} & \multirow[t]{2}{*}{ df } & \multirow[t]{2}{*}{$\begin{array}{l}\text { Sig. (2- } \\
\text { tailed) }\end{array}$} & \multirow[t]{2}{*}{$\begin{array}{l}\text { Mean } \\
\text { Difference }\end{array}$} & \multirow[t]{2}{*}{$\begin{array}{l}\text { Std. Error } \\
\text { Difference }\end{array}$} & \multicolumn{2}{|c|}{$\begin{array}{l}95 \% \text { Confidence } \\
\text { Interval of the } \\
\text { Difference }\end{array}$} \\
\hline & & & & & & & & & Lower & Upper \\
\hline \multirow{2}{*}{$\begin{array}{l}\text { Total } \\
\text { EQ }\end{array}$} & $\begin{array}{l}\text { Equal variances } \\
\text { assumed }\end{array}$ & 2.884 & .094 & -3.325 & 68 & .001 & -30.558 & 9.189 & -48.895 & -12.221 \\
\hline & $\begin{array}{l}\text { Equal variances } \\
\text { not assumed }\end{array}$ & & & -3.226 & 54.6 & 5.002 & -30.558 & 9.472 & -49.542 & -11.574 \\
\hline
\end{tabular}

In the Independent Samples Test (Table 7), the mean differences were $(\mathrm{M}=30.558)$ that is less than 0.05. Thus, there was a difference between EQ of male and female teachers .

And to see if there is any difference between Iranian EFL teachers' job satisfaction in terms of gender, the same procedure was run.

Table 8. Descriptive statistics for JS among male and female teachers

\begin{tabular}{llllll}
\hline & Gender & $\mathrm{N}$ & Mean & Std. Deviation & Std. Error Mean \\
\hline \multirow{2}{*}{ Total J.S } & man & 30 & 105.30 & 15.066 & 2.751 \\
& woman & 40 & 108.90 & 16.597 & 2.624 \\
\hline
\end{tabular}

As we can see in Table 8, there was no significant difference in the scores of job satisfaction of male and female teachers. JS score of men was $\mathrm{M}=105.30, \mathrm{SD}=15.066$ and that of women was $\mathrm{M}=108.90, \mathrm{SD}=16.597$.

Table 9. Independent sample t-test for both groups: J.S among male and female teachers

\begin{tabular}{|c|c|c|c|c|c|c|c|c|c|}
\hline & & \multicolumn{8}{|c|}{$\begin{array}{l}\text { Levene's Test } \\
\text { for Equality of t-test for Equality of Means } \\
\text { Variances }\end{array}$} \\
\hline & & \multirow[t]{2}{*}{ Sig. } & \multirow[t]{2}{*}{$\mathrm{t}$} & \multirow[t]{2}{*}{ df } & \multirow{2}{*}{$\begin{array}{l}\text { Sig. }(2- \\
\text { tailed) }\end{array}$} & \multirow{2}{*}{$\begin{array}{l}\text { Mean } \\
\text { Difference }\end{array}$} & \multirow{2}{*}{$\begin{array}{l}\text { Std. Error } \\
\text { Difference }\end{array}$} & \multicolumn{2}{|c|}{$\begin{array}{l}95 \% \text { Confidence Interval } \\
\text { of the Difference }\end{array}$} \\
\hline & & & & & & & & Lower & Upper \\
\hline \multirow{2}{*}{$\begin{array}{l}\text { Total } \\
\text { J.S }\end{array}$} & $\begin{array}{l}\text { Equal variances } \\
\text { assumed }\end{array}$ & \multirow[t]{2}{*}{.060 .808} & -.934 & 68 & .354 & -3.600 & 3.855 & -11.293 & 4.093 \\
\hline & $\begin{array}{l}\text { Equal variances } \\
\text { not assumed }\end{array}$ & & -.947 & 65.4 & 0.347 & -3.600 & 3.802 & -11.191 & 3.991 \\
\hline
\end{tabular}


In the Independent Samples Test table, the mean difference was $\mathrm{M}=3.6$ and the $\mathrm{Sig}=\mathrm{p}$-Value $=0.354$ that is greater than 0.05 ; therefore, there was no statistically significant difference between our two variables.

\section{Discussion}

Analysis of the findings concerning our research question (Is there any relationship between Iranian EFL teachers' emotional intelligence and their job satisfaction?) revealed that there was a positive and significant correlation between EI and JS of EFL teachers in Iran/Shiraz. In other words, the more the EI of EFL teachers, the more their JS, perhaps because if teachers have a high EI, they should have a positive perspective on their work environment and current situations at work, as well (Anari, 2012; Mousavi et al. 2012). This may explain the cause of greater teaching enjoyment by teachers with high EI than those with lower EI.

Comparison of the results of this study specifically with teacher-related studies revealed that our finding is in line with those of Anari's (2012) study in which a positive significant relationship was found between JS and EI of Iranian English high school teachers. Similarly, in another study conducted in Iran, Yahyazadeh-Jeloudar and Lotfi-Goodarzi (2012) reported a significant relationship between EI and JS of senior secondary school teachers. Likewise, this relationship between EI and JS was supported by another study conducted in Iran but this time on physical education teachers (Mousavi et al., 2012). This finding seems to also agree with the observations of Salim et al. (2012) on 1200 primary and secondary Malaysian school teachers from 60 schools. In this study, too, a significantly positive relationship was found between EI of these teachers and their JS. Moreover, in another study regarding 398 secondary school Nigerian teachers, Akomolafe and Ogunmakin (2014) also reached the conclusion that EI can significantly predict JS. Finally, Cobb (2004) also found a positive relationship between JS and EI of American public school teachers. Although from a different nature, Cobb (2012) studied the relationship between the principles' emotional intelligence and their teachers' job satisfaction and he rejected the existence of a relationship between the two variables of his study.

As to the studies related to other professions, the relationship between employees' EI and their JS has been well documented in many studies reviewed in the literature (Abraham, 2000; Busso, 2003; Platsidou, 2010, and Najafi \& Mousavi, 2012); however, these findings are in contrast with those of similar studies conducted by Hendee (2002) and Donaldson-Feilder and Bond (2004) who found no association between EI and JS of the employees. One reason for the discrepancies observed between these results, according to Donaldson-Fielder and Bond (2004), is the nature of selfreport measures in evaluating EI. They believe that since EI is strongly associated with self-awareness, when asked to rate themselves, those who are self-aware may judge themselves high achievers while those who are not may consider themselves low achievers when judging their EI (Donaldson-Fielder and Bond, 2004, p.12).

Furthermore, this study found that out of the four dimensions of JS, only one which is teaching motivation is related to the EI. Indeed, Pearson correlation exhibited a moderate relationship between EFL teachers' EI and motivation (pvalue $=r=0.573$ ) which means that teachers with more EI can create positive emotions in themselves and others in order to have a successful communication with or impart their knowledge to students. Moreover, among all motivation components, learning beliefs and teacher personality contributed highly to the students' satisfaction. This might have been the case since those teachers who have a more control over their learner and themselves are advantageous over others due to their higher degrees of motivation which result from high EI. According to Cherniss (2001), individuals who have a high level of EI produce a satisfactory, harmonious, and encouraging environment which will in turn provide them with happiness in jobs that they strive for. This result confirms the findings of Karavas (2010) and Day (2002), highlighting that intrinsic nature of the job, i.e. teaching, gives teachers the greatest motivation.

To answer the second research question, statistical analysis of the data revealed that there was a statistically significant difference in emotional intelligence between EFL male and female teachers. In the present study, EFL female teachers' emotional intelligence scored slightly higher than male teachers. Also, the majority of the female teachers had high levels of EI (mean score was 331.53) and the majority of male teachers had a moderate level of EI (mean score was 300.97).

The above-mentioned finding is consistent with those of Mayer, Caruso, and Salovey (1999) who found that women scored higher than the men. Correspondingly, Ciarrochi, Chan, and Caputi, (2000) who applied the MEIS (Multifactor Emotional Intelligence Scale), carried out a study on 31 male and 103 female Australian undergraduate students and discovered that female students outperformed the male ones. Other studies (Petrides, Furnham, \& Martin 2004) have come to similar results in which emotional intelligence is in favor of females. Some reasons mentioned in the literature for the female's emotional intelligence superiority are the fact that females might be socially more sensitive towards emotions than men (Ciarrochi, Chan, \& Caputi, 2000), or they might be biologically inclined to outperform males emotionally (Mayer, Caruso, \& Salovey, 1999). However, this result was against the finding of Hans et al. (2013), in which the researches could not find any significant difference between male and female teachers' emotional intelligence in Oman based on descriptive statistics. It was inferred that male and female teachers were emotionally matured and stable while conveying the knowledge in Oman.

Finally, the analysis of our data in order to investigate the difference existing between the job satisfaction of EFL female and male teachers of private institutes in Shiraz demonstrated that there was no difference between job satisfaction of EFL male and female teachers. Findings of the present research are in line with some rather older studies conducted by Ely (1993), Haddad (1989), Haywood (1980), and Stiles (1993), Beck (2002), Bright (2002) and finally Klein (2007) who looked into gender and found no gender effect on the level of job satisfaction. However, the finding 
of this study is not in agreement with the results reported by Abdullah and Salahudin (2007). They conducted a study on job satisfaction among secondary school teachers. This survey was carried out among 200 teachers. They concluded that male teachers are generally more satisfied with their jobs in comparison with the females. And Ladebo (2005) showed that Nigerian female teachers are more satisfied with their jobs than the male teachers.

\section{Conclusion}

Many of the studies existing in literature have focused on the relationship between EI and JS among employees in general regardless of the fact that they work in public or private sectors. On the contrary, this study concentrated only on EFL teachers who work at private sectors in which they might often be deprived from their occupational rights. Nevertheless, the findings of this study showed that working at private sectors, in this case teaching English at private institutes with low income, or not very suitable conditions to work with lack of job security, did not really affect the relationship found in this study between EI and JS. And this once again emphasizes the fact that how essential EI is in the workplace whether it is considered to be a range of abilities related merely to reflecting and drawing conclusions or abilities associated with character trait and motivation (Bar-on, 2000; Mayer et al. 2000). Indeed, when interaction occurs between people every day and all day in the workplace, the quality of those interactions affect decision, outcomes, perception, and the approach people use in dealing with one another. Individuals who have the ability to perceive emotion in others, use this emotion to facilitate thinking and managing other's and their own emotion, and they have an advantage in dealing successfully with people on the job. Thus, the researchers can conclude that the emotionally-intelligent teachers might understand their students' feelings better. In turn, this may influence the teacherstudent relationships and interactions. Teachers who are not comfortable with 'touchy feely' matters should be educated in order to understand that emotions are as similarly important as intelligence if a person wants to educate the child completely (Harbour \& Stewart, 1997, p. 194).

Based on the findings of this study, the researchers can suggest that remedial and in-service trainings are done to aid teachers in enhancing their EI in case teachers' EI is low (Goleman, 1998). If mediations like these are considered in public or private institutions, not only the maintenance rate among effective teachers may enhance, but also their productivity will be increased. Emotions can lead to assurance and commitment, thereby increasing JS and productivity in the organization (Cooper \& Schabracq, 1998). The incorporation of some preparatory courses allocated to enhancing such vital psychological traits like EI for novice teachers is thought to contribute to pedagogical strengthening. This finding may also trigger organizational managers to perceive and enhance JS and productivity through focusing more on psychological issues involved in employment.

As a final remark, though, it is worth mentioning that while this study focused on 70 EFL teachers working at 6 language centers in one district in Shiraz/Iran, the findings may be relevant to teachers with similar profile characteristics and to geographical districts with moderate economic level. Above all, although EFL teachers from different Asian countries may share some cultural commonalities, the findings of this study may only mirror the results that would be obtained perhaps from similar cultural practices and beliefs in the similar region.

\section{References}

Abdullah, M. M., Uli, J., \& Salahudin, S. M. (2007). Job satisfaction of secondary school teachers in tawau, Sabah. Unpublished master's thesis, Universiti Tenaga Nasional, Malaysia.

Abraham, R. (2000). The Role of Job Control as a Moderator of Emotional Dissonance and Emotional IntelligenceOutcome Relationships. The Journal of Psychology, 134(2), 169-184.

Alam, M. M. (2009). The Relationships between the Emotional Intelligence and Job Satisfaction: Empirical Findings from Higher Education Institution in Malaysia. Journal of Management and Social Sciences, 5(2), 124-139.

Akomolafe, M. J., \& Ogunmakin, A. O. (2014). Job Satisfaction among Secondary School Teachers: Emotional Intelligence, Occupational Stress and Self-Efficacy as Predictors. Journal of Educational and Social Research, 4(3), 487.

Anari, N. N. (2012). Teachers: emotional intelligence, job satisfaction, and organizational commitment. Journal of workplace Learning, 24(4), 256-269.

Argyle, M. (1989). The Psychology of Happiness, Routledge, London.

Bar-On, R. (1997). Bar-On Emotional Quotient Inventory (EQ-I): Technical Manual Toronto, Ontario, Canada: MultiHealth Systems.

Barr, R., Kamil, M., Mosenthal, P., \& Pearson, D. (2002). The handbook of reading research. Mahwah, NJ: Lawrence Erlbaum.

Beck, S. E. (2002). Civil service engineers after the Cold War: An examination of job satisfaction. Dissertation Abstracts International, 63 (04).

Borzaga, C., \& Tortia, E. (2006). Worker Motivations, Job Satisfaction, and Loyalty in Public and Nonprofit Social Services. Nonprofit and Voluntary Sector Quarterly, 35, 225-248.

Bright, M. L. (2002). Job satisfaction as an indicator for retention of new community college instructional faculty. Dissertation Abstracts International, 63(05), 1635.

Busso, L. (2003). The Relationship between Emotional Intelligence and Contextual Performance As Influenced By Job Satisfaction and Locus as Control Orientation. Dissertation abstract international, 64 (10). 
Carmeli, A. (2003). The Relationship between Emotional Intelligence and Work Attitudes, Behavior and Outcomes: An Examination among Senior Managers. Journal of managerial Psychology, 18(8), 788-813.

Chaplain, R. P. (2008). Stress and psychological distress among trainee secondary teachers in England. Educational Psychology, 28 (2), 195-209.

Chen, W. (2007). The structure of secondary school teacher job satisfaction and its relationship with attrition and work enthusiasm. Chinese Education and Society, 40(5), 17-31.

Cherniss, C. (2000, April). Emotional intelligence: What it is and why it matters. Paper presented in annual meeting of the Society for Industrial and Organizational Psychology, New Orleans, LA (Vol. 15).

Cherniss, C. (2001). Emotional Intelligence and the Good Community. American Journal of Community Psychology, 30 (1), 1-11.

Ciarrochi, J., Chan, A.Y.C., \&Caputi, P. (2000). A critical evaluation of the emotional intelligence construct. Personality and Individual Differences, 30, 539-561.

Cobb, B. (2004). Assessing job satisfaction and emotional intelligence in public school teachers. Unpublished master's thesis. Bowling Green, OH: Bowling Green State University.

Cobbs, R.E. (2012). Is the Emotional Intelligence of Secondary School Principals Correlated with the Job Satisfaction or Performance of their Teachers? Unpublished master's thesis. University of Kansas.

Cooper, C. L., \& Schabracq, M. J. (1998). Flexibility of labor, well-being, and stress. International Journal of Stress Management, 4(4), 259.

Creswell, J. W. (2003). Research design qualitative, quantitative, and mixed methods approaches (2nd ed.). Thousand Oaks, CA: Sage.

Day C. (2002). The Challenge to Be Best: Reckless Curiosity and Mischievous Motivation.

Teacher and Teaching: Theory and Practice 8, 3/4, 421-434.

Dinham, S., \& Scott, C. (2000). Moving into the third, outer domain of teacher satisfaction. Journal of Educational Administration, 38, 379-396.

Donaldson-Fielder, E.J. \& Bond, F.W. (2004). The Relative Importance of Psychological Acceptance and Emotional Intelligence to Workplace Well-Being. Br. J. Guidance and Counselling, 32, 187-203.

Ely, T. C. (1993). Job satisfaction of public school teachers in Ohio: A comparison of the similarities and differences between male and female teachers. Dissertation Abstracts International, 55 (01).

Fenech, M. (2006). The impact of regulatory environments on early childhood professional practice and job satisfaction: A review of conflicting discourses. Aust. J. Early Childhood, 31(2), 49-57.

Ghazi, S. R., Ali, R., Shahzada, G., \& Israr, M. (2010). University Teachers' Job Satisfaction in the North West Frontier Province of Pakistan. Asian Social Science, 6(11), p.188.

Goleman, D. (1995). Emotional intelligence: Why it can matter more than IQ. New York: Bantam Books.

Goleman, D. (1998). Working with Emotional Intelligence. New York: Bantam Books.

Goleman, D (2001). Emotional intelligence: Issues in paradigm building. In C. Cherniss \& D. Goleman (Eds.), The Emotionally Intelligent Workplace, (pp. 13-26), Jossey-Bass: San Francisco.

Haddad, N. A. (1989). Why nurses stay: The relationship of personality to job and career satisfaction (job satisfaction). Dissertation Abstracts International, 51 (02).

Hans, A. Mubeen, S. A. \& Al Ghabshi, A. S. (2013). A Study on Locus of Control and Job Satisfaction in SemiGovernment Organizations in Sultanate of Oman. The SIJ Trans. Ind. Financial and Bus. Manage. 1(2), 93-100.

Harbour, P. M. \& Stewart, J. (1997). Emotional regulation during childhood: Educator's commentary. In P. Salovey \& D. J. Sluyter, (Eds.), Emotional development and emotional intelligence (pp. 193-195). New York, NY: Basic Books.

Haywood, G. D. (1980). The relationship of job satisfaction, job satisfactoriness and personal characteristics of secondary school teachers in Georgia (Doctoral dissertation, ProQuest Information \& Learning).

Heller, D., Judge, T. A., \& Watson, D. (2002). The confounding role of personality and trait affectivity in the relationship between job and life satisfaction. Journal of Organizational Behavior, 23(7), 815-835.

Hendee, S. S. (2002). Measurement of differences in emotional intelligence and job satisfaction of practicing chefs and culinary educators as measured by the Mayer-Salovey-Caruso Emotional Intelligence Test and Spector's Job Satisfaction Survey. Doctoral dissertation, New York University, United States-New York.

Izaguirre, R. (2008). The relationship among emotional intelligence, academic achievement, and demographic characteristics in first year community college students. $\mathrm{PhD}$, University of the Incarnate Word. Retrieved from http://www.proquest.com/en-US/products/dissertations/individuals.shtml

Iwanicki, E. (2001). Understanding and Alleviating Teacher Burnout. Theory into Practice, 22, 27-32.

Kafetsios, K., \& Loumakou, M. (2007). A Comparative Evaluation of the Effects of Trait Emotional Intelligence and Emotion Regulation on Affect at Work and Job Satisfaction. International Journal of Work Organization and Emotion, 


\section{2(1), 71-87.}

Karavas, E. (2010). How satisfied are Greek EFL Teachers with their Work? Investigating the Motivation and Job Satisfaction Levels of Greek EFL Teachers. Porta Linguarum, 14, 59-78.

Kappagoda, S. (2011). The Relationship between Principals' Emotional Intelligence and Teachers' Job Satisfaction: A Case of National Schools in Sri Lanka (October 20). International Conference on Business \& Information, 2011. Retrieved from: http://ssrn.com/abstract=2216372

Kim, S. (2004). Factors Affection State Government Information Technology Employee Turnover Intentions. American Review of Public Administration, 35, 137-156.

Klein, J. J. (2007). The relationship between job satisfaction and leadership practices: A survey-based analysis of fulltime business faculty in the Wisconsin Technical College System (Doctoral dissertation, Capella University).

Kremenitzer, J., \& Miller, R. (2008). Are you a highly qualified, emotionally intelligent early childhood educator? YC Young Children, 63(4), 106-108.

Kulshrestha, U. \& Sen, C. (2006). Subjective Well-Being in Relation to Emotional Intelligence and Locus of Control among Executives. Journal of the Indian Academy of Applied Psychology, 32(2), 129-134.

Ladebo, O. J. (2005). Effects of Work-related Attitudes on the Intention to Leave the Profession: An Examination of School Teachers in Nigeria. Educational Management Administration \& Leadership, 33(3), 355-369.

Levy, A. J., Fields, F. T., \& Jablonski, E. S. (2006). Overview of research: What we know and don't know about the consequences of science and math teacher turnover. Paper presented at the NSFSponsored National Commission on Teaching and America's Future (NCTAF) symposium on the scope and consequences of K-12 science and mathematics teacher turnover, Racine, WI.

Mayer, J. D., Caruso, D. R., \& Salovey, P. (1999). Emotional intelligence meets traditional standards for an intelligence. Intelligence, 27(4), 267-298.

Mayer, J. D., DiPaolo, M. T., \& Salovey, P. (1990). Perceiving Affective Content in Ambiguous Visual Stimuli: A Component of Emotional Intelligence. Journal of Personality Assessment, 54, 772 - 781.

Mayer, J. D., Salovey, P. \& Caruso, D. R. (2000b). Models of Emotional Intelligence. In R. J. Sternberg (Ed.), Handbook of intelligence, (pp. 396-420). New York, NY: Cambridge University Press.

Milkovich, G.T. \& Boudreau, J. W. (1988). Personnel/Human Resource Management: A Diagnostic Approach. Fifth edition. Plan, Texas: Business Publications.

Mousavi, S.H., Yarmohammadi, S., Nosrat, A.B. \& Tarasi, Z. (2012). The Relationship between Emotional Intelligence and Job Satisfaction of Physical Education Teachers. Annals of Biological Research, 3(2), 780-788.

Najafi, M. \& Mousavi, S. (2012). Studying the Effect of Emotional Quotient on Employee's Job Satisfaction (The Case of Isfahan University of Medical Sciences). Interdisciplinary Journal of Contemporary Research in Business, 4(2), 343

Parker, C. P., Baltes, B. B., Young, S. A., Huff, J. W., Altmann, R. A., Lacost, H. A., \& Roberts, J. E. (2003). Relationships between Psychological Climate Perceptions and Work Outcomes: A Meta-Analytic Review. Journal of Organizational Behavior, 24(4), 389-416.

Petrides, K. V., Furnham, A. \& Martin, G. N. (2004). Estimates of emotional andpsychometric intelligence: Evidence of gender-based stereotypes. The Journal of Social Psychology, 144(2), 149-162.

Pishghadam, R., \& Sahebjam, S. (2012). Personality and Emotional Intelligence in Teacher Burnout. The Spanish journal of psychology, 15(01), 227-236.

Platsidou, M. (2010). Trait Emotional Intelligence of Greek Special Education Teachers in Relation To Burnout and Job Satisfaction. School Psychological Int., 31, 60-76.

Rowden R.W. (2002). The relationship between workplace learning and Job satisfaction in US small midsize businesses, Human Resource Development Quarterly, 13 (4), 407-25.

Saavedra R, \& Kwun, SK. (2000). Affective states in job characteristics theory. Journal of

Organizational Behavior, 21, 131-146.

Salim, S. S., Nasir, R., Arip, M. A. S. N., \& Mustafa, M. (2012). The role of emotional intelligence on job satisfaction among school teachers. The Social Sciences, 7(1), 125-129.

Sammons, P. (2007) School effectiveness and equity: making connections. Executive summary. CfBT.

Sammons, P. \& Bakkum, L. (2012) Effective Schools, Equity and Teacher Effectiveness: A Review of the Literature, Profesorado Revista de curriculum y formación del profesorado, 15, (3) 9-26.

Shann, M. (1998). Professional Commitment and Satisfaction among Teachers in Urban Middle Schools. The Journal of Educational Research, 92, 67-75.

Stein, S. J., \& Book, H. E. (2006). The EQ Edge: Emotional Intelligence and Your Success.

Mississauga, ON: Jossey Bass. 
Stiles, D. C. (1993). The relationship between organizational climate and teacher job satisfaction in Gwinnett County public schools. Unpublished doctoral dissertation. University of Georgia, Athens, GA.

Syptak, J. M., Marsland, D. W., \& Ulmer, D. (1999). Job satisfaction: Putting theory into practice. Family Practice Management, 6, 26-31.

Tabatabaee Yazdi, M. Motallebzadeh, Kh \& Ashraf, H. (2013). Iranian EFL Teachers' Self-Efficacy and Teachers' Burnout: A Case of Comparison. International Journal of Language Learning and Applied Linguistics World, 4(2), 5973.

Vacola, M., Tsaousis, I., \& Nikolaou, I. (2003). The Role of Emotional Intelligence and Personality Variables on Attitudes Toward Organizational Change. Journal of Managerial Psychology, 19(2), 88-110.

Wiener, Y., \& Vardi, Y. (1980). Relationships between Job, Organization, and Career Commitments and Work Outcomes-An Integrative Approach. Organizational Behavior and Human Performance, 26(1), 81-96.

Wright, B. E., \& Davis, B. S. (2003). Job Satisfaction in the Public Sector; the Role of the Work Environment. The American Review of Public Administration, 33(1), 70-90.

Yahyazadeh-Jeloudar, S., \& Lotfi-Goodarzi, F. (2012). What is the Relationship between Spiritual Intelligence and Job Satisfaction among MA and BA Teachers. International Journal of Business and Social Science, 3(8), $299-303$. 